AGRICA: Journal of Sustainable Drayland Agriculture, 14 (1): 67-82 (2021)

ISSN-Online: 2715-4955; ISSN-Cetak: 2715-6613

DOI: https://doi.org/10.37478/agr.v14i1.1042

\title{
PENGARUH BIOCHAR SEKAM PADI TERHADAP SIFAT FISIK TANAH DAN HASIL TANAMAN JAGUNG (Zea mays) DI KELURAHAN LAPE KECAMATAN AESESA
}

\author{
Yosefina F. Janu dan Charly Mutiara \\ Program studi Agroteknologi, Fakultas Pertanian Universitas Flores \\ Jln. Sam Ratulanggi XX Paupire, Ende, Nusa Tenggara Timur \\ charlyinter1988@gmail.com
}

\begin{abstract}
Effect of Rice Husk Biochar on Physical Properties of Soil and Corn (Zea mays) Yield in Lape Village, Aesesa District. This study aims to determine the condition of the physical properties of the soil and maize yields given rice husk biochar in Lape Village, Aesesa District. The continuous use of inorganic fertilizers will have a negative impact on the soil such as destroying the physical properties of the soil and reducing maize yields. Therefore, this research is a descriptive study. Determination of soil samples using purposive sampling method with the criteria of land cultivation of corn and rice husk biochar. The variables observed were soil color, structure, texture, porosity, bulk density, moisture content, temperature, humidity and maize yield. The results showed that the criteria for the physical properties of the soil in the maize cultivation area were dusty clay soil texture and categorized as S1 class, soil color was dominated by 10 YR 2/1 Black and categorized as S1 class, and soil structure was dominated by granular criteria. B0 content density value: 1.01 ; B2: 0.9; B3: 0.87; B4: 0.81; B4: 0.8 and categorized as S2 class, soil porosity value B0: 61.76; B1: 65.91; B2:67, 18; B3: 69.41; B4; 69.89 and categorized as S1 class. Value of water content B0: 36.78; B1:41,14; B2: 40.82; B3: 35.06; B4: 39.55 and categorized into class $\mathrm{N}$. temperature analysis results B0: 33.75; B1: 34.00; B2: 32.75; B3: 33.25; B4: 34.00 and can be categorized as class N. Moisture analysis results B0: 67.00; B1: 68.00; B2: 64.50; B3: 66.25; 68.00 and categorized in S1 class. And maize yields. Corn kernels yield tan-1(g) B0: 347.30; B1: 360.40; B2: 380.70; B3: 385.40; B4: 401.35. Yield of shelled corn ha-1(tons) B0: 9.26; B1: 9.61; B2: 10,15; B3: 10.28; B4: 10.70
\end{abstract}

Key words : Biochar rice husk, Corn crop, Soil physical properties

PENDAHULUAN

Komoditi jagung ( Zea mays L.)

merupakan salah satu tanaman serelia yang

strategis dan bernilai ekonomi serta mempunyai peluang untuk dikembangkan.

Tanaman ini memiliki kedudukan sebagai sumber utama karbohidrat selain beras. Jagung juga ditanam sebagai pakan ternak dan bahan baku industri. Upaya peningkatan produksi tanaman jagung masih menghadapi berbagai masalah seperti kurang suburnya 
tanah serta serangan hama dan penyakit tanaman (Wahyudin et al., 2017).

Berdasarkan hasil wawancara terhadap petani jagung di Kelurahan Lape Kecamatan Aesesa, pemupukan tanaman jagung yang digunakan di Kelurahan Lape adalah menggunakan pupuk anorganik, seperti Urea. Pupuk ini sulit didapatkan petani sesuai kebutuhan dan waktu, karena harus dibeli secara kelompok. Masalah lain dari pupuk urea ini adalah aplikasi pupuk urea dengan dosis tinggi. Pemberian pupuk urea oleh petani pada tanaman jagung sebanyak 300 kg/ha. Berdasarkan Balai Pengkajian Teknologi Pertanian pupuk anorganik urea yang dianjurkan pada tanaman jagung adalah 150-200 kg/ha (BPTP, 2010). Selain masalah diatas, masalah lain yaitu pengolahan tanah yang intensif. Menurut Fuady dan Mustaqim (2015) pengolahan tanah yang intensif secara tidak langsung dapat menyebabkan kerusakan pada tanah baik disebabkan oleh erosi maupun aktivitas pengolahan tanah tersebut.

Kecendrungan petani saat ini adalah dengan menggunakan pupuk kimia (anorganik) dengan alasan kepraktisannya. Penggunaan pupuk anorganik dalam jangka panjang menyebabkan kadar bahan organik tanah menurun, sifat fisik tanah rusak, dan pencemaran lingkungan (Simanjuntak et al.,
2013; Herdiyanto dan Setiawan, 2015). Untuk mengatasi hal tersebut dapat digunakan limbah hasil pertanian seperti sekam padi yang dapat diubah menjadi arang atau biochar (arang aktif). Pemanfaatan limbah hasil pertanian merupakan salah satu solusi untuk memperbaiki kualitas tanah yang sudah tercermar karena penggunaan pupuk kimiawi yang berlebihan (Kresnatita et al., 2013).

Biochar atau arang hitam merupakan hasil dari proses pembakaran biomassa. Biomassa yang digunakan umumnya berasal dari limbah hasil pertanian, kemudian dilakukan pembakaran dalam keadaan oksigen terbatas atau tanpa oksigen (Akmal dan Simanjuntak, 2019). Biochar memiliki sifat stabil yang dapat dijadikan sebagai pembenah tanah. Berbagai macam penelitian yang telah dilakukan menunjukkan bahwa biochar bermanfaat untuk memperbaiki kualitas secara fisik dengan meningkatkan kapasitas menahan air dan kemantapan agregat, memperbaiki berat isi dan menurunkan ketahanan tanah karena strukturnya yang berpori (Syaikhu et al., 2016). Pemberian biochar ke dalam tanah sangat berpotensi untuk meningkatkan Corganik tanah dan retensi air dan unsur hara lainnya dalam tanah (Herman dan Resigia, 2018). Berdasarkan penelitian (Khoiriyah et 
Janu: Pengaruh biochar sekam padi terhadap sifat fisik dan hasil tanaman jagung

al., 2016 ) salah satu upaya untuk menjaga ketersediaan air tanah yang dapat dilakukan dengan pemberian biochar. Penambahan biochar akan meningkatkan kapasitas menahan air tanah. Jika kapasitas menahan air ditingkatkan, maka ketersediaan air tanaman menjadi meningkat.

Pertumbuhan tanaman dipengaruhi oleh keadaan sifat fisik tanah. Sifat fisik tanah mempengaruhi pertumbuhan akar tanaman untuk mencari air dan unsur hara. Perkembangan akar tanaman membutuhkan kondisi tanah yang gembur. Akar tanaman tidak dapat berkembang dengan baik apabila tanah mengalami pemadatan, sehingga tanaman akan terganggu dalam menyerap air dan unsur hara. Pemberian bahan organik seperti biochar perlu dilakukan agar dapat mengoptimalkan kualitas fisik tanah sehingga tanaman bisa tumbuh optimal (Widodo dan Kusuma, 2018).

Biochar sekam padi dapat memperbaiki tanah dan dapat meningkatkan produktivitas tanaman. Penambahan biochar dalam tanah mampu meningkatkan ketersedian hara bagi tanaman tanaman. Verdiana et al. (2016) mengatakan bahwa biochar sekam padi memiliki kandungan Corganik $30.76 \%$, sehingga biochar sekam padi dapat memiliki waktu yang cukup lama untuk berada dalam tanah sekitar lebih dari1000 tahun (Akmal dan Simanjuntak, 2019) mengatakan bahwa sekam padi dari proses penggilingan dapat dimanfaatkan sebagai bahan pembenah tanah yang dapat mengubah sifat fisika, kimia dan biologi tanah, dapat meningkatkan kualitas lahan pertanian, mampu mengurangi sampah biomassa dan dapat meningkatkan $\mathrm{pH}$ tanah atau mengurangi keasamaan tanah (Widiastuti dan Lantang, 2017).

Pemanfaatan limbah pertanian seperti biochar sekam padi untuk kegiatan ramah lingkungan dalam skala luas belum direalisasikan dan dikenal di kalangan petani. Pengaplikasian biochar 2 ton/ha dalam tanah mampu meningkatkan ketersediaan hara bagi tanamandan memperbaiki sifat fisik tanah (Verdiana et al., 2016). Penelitian ini bertujuan untuk mengetahui kondisi sifat fisik tanah dan hasil tanaman jagung yang diaplikasikan biochar sekam padi.

\section{BAHAN DAN METODE}

Penelitian ini dilaksanakan di Kelurahan Lape, Kecamatan Aesesa, Kabupaten Nagekeo dan berrlangsung selama 3 bulan yaitu dari bulan Juli sampai Oktober 2020. Bahan yang digunakan dalam ini adalah biochar sekam padi, dan benih jagung pulut. Alat yang digunakan dalam percobaan ini meliputi cangkul, ember, sekop, timbangan duduk, alat tulis, ring, 
kantong plastik, tali rafia, terpal, ayakan, gunting, mistar, drum.

Rancangan yang digunakan adalah rancang acak kelompok (RAK). Dengan pola factor tunggal yang terdiri dari 5 perlakuan :

B0 $=0 \mathrm{~kg} \mathrm{ha}^{-1}$ (kontrol)

$\mathrm{B} 1=1$ ton $/ \mathrm{ha}^{-1}$ biochar sekam padi $=0,9375$

$\mathrm{B} 2=2$ ton $/$ ha biochar sekam padi $=1,875 \mathrm{~kg}$ $=2 \mathrm{~kg}$

$\mathrm{B} 3=3$ ton $/$ ha biochar sekam padi $=2,8125$ $\mathrm{kg}=2,81 \mathrm{~kg}$

$\mathrm{B} 4=4 \mathrm{ton} / \mathrm{ha}^{-1}$ biochar sekam padi $=3,75 \mathrm{~kg}$ Masing-masing perlakuan diulang sebanyak 4 kali sehingga terdapat petak percobaan.

Pelaksanaan penelitian dimulai dengan menyiapkan sekam padi, lalu sekam yang telah disiapkan dibakar hingga menjadi arang kemudian disiram dengan air. Setelah itu lahan diolah dengan menggunakan cangkul dengan kedalaman $20 \mathrm{~cm}$, di gembur dan diratakan. Pembentukan ukuran bedeng dengan tinggi $15 \mathrm{~cm}$, kemudian petak percobaan dibuat bedeng dengan ukuran Panjang $375 \mathrm{~cm}(3,75 \mathrm{~m})$ dan lebar $250 \mathrm{~cm}$ $(2,50 \mathrm{~m})$ dengan jarak antara petak $25 \mathrm{~cm}$ dan jarak antara blok $20 \mathrm{~cm}$. Setelah lahan selesai diolah, benih jagung di tanam dengan jarak tanam 75 x $50 \mathrm{~cm}$. Pupuk susulan dengan menggunakan pupuk NPK Pelangi dengan dosis $10 \mathrm{gr} / \mathrm{tanaman}$. Sedang biochar digunakan 1-2minggu sebelum tanam.

Paramater yang diamati adalah warna tanah, struktur, tekstur, suhu, kelembaban, kadar air, kerapatan isi, porositas, berat pipilan jagung $\tan ^{-1}$ (gr) dan berat pipilan jagung ha-1 (ton). Data pengamatan variabel hasil dianalisis dengan menggunakan analisis sidik ragam. Apabila perlakuan menunjukan pengaruh yang nyata terhadap variabel yang diamati, maka pengujian dilanjutkan dengan uji nilai beda rata-rata menggunakan uji BNT 5\% (Gomez dan Gomez, 2007). Sedangkan untuk melihat variabel sifat fisik tanah dengan menggunakan analisis kesesuaian lahan dari Pusat Penelitian Tanah Bogor (1995).

\section{HASIL DAN PEMBAHASAN}

\section{Warna, Tekstur dan Struktur Tanah}

Sifat fisik tanah merupakan penentu tingkat kesuburan suatu tanaman. Beberapa sifat fisik tanah telah dianalisis dalam penelitian ini. Hasil analsis warna, tekstur dan struktur tanah dapat dilihat pada Tabel 1. 
Janu: Pengaruh biochar sekam padi terhadap sifat fisik dan hasil tanaman jagung

Tabel 1. Hasil Analisis Warna, Tekstur dan Struktur Tanah Pada Lahan budidaya tanaman jagung di Kelurahan Lape

\begin{tabular}{lcccc}
\hline NO & Kode Sampel & Warna Tanah & Tekstur Tanah & Struktur Tanah \\
\hline 1 & B0 & 10YR2/1-Black & Lempung Berdebu & Granular \\
2 & B1 & 10YR2/1-Black & Lempung Berdebu & Granular \\
3 & B2 & 10YR2/1-Black & Lempung Berdebu & Granular \\
4 & B3 & 10YR2/1-Black & Lempung Berdebu & Granular \\
5 & B4 & 10YR2/1-Black & Lempung Berdebu & Granular \\
\hline
\end{tabular}

Menurut penelitian (Umin dan Anasaga, 2019) tanah yang mengandung bahan organik tinggi 3,01\% akan berwarna gelap, sebaliknya semakin rendah $1,0 \%$ kandungan bahan organik maka tanah akan berwarna semakin terang akumulasi dari bahan organik akan menciptakan warna kehitaman pada suatu tanah atau lahan.

Hal ini sesuai dengan pendapat Holilullah et al. (2015) bahwa warna tanah dipengaruhi oleh beberapa faktor, antara lain bahan organik yang menyebabkan warna gelap. Perbedaan warna permukaan tanah umunya dipergaruhi oleh perbedaan pemberian kandungan bahan organik. Makin tinggi kandungan bahan organik yang diberi, warna tanah cenderung gelap. Sebaliknya semakin rendah kandungan bahan organik maka tanah akan berwarna semakin cenderung terang akumulasi dari bahan organik akan menciptakan warna kehitaman pada suatu tanah atau lahan.
Hasil penelitian tentang tekstur tanah menunjukkan bahwa kondisinya di lahan budidaya tanaman jagung bertekstur lempung berdebu di setiap perlakuan. Dari perlakuan yang diberikan biochar menunjukan tidak ada perbedaan pada semua perlakuan, yang berarti tekstur tanah bersifat homogen. Hal ini didukung oleh penelitian Khoiriyah et al. (2016) dengan pemberian perlakuan biochar tidak berpengaruh terhadap tekstur tanah, sehingga tekstur tanah dapat digunakan untuk mendapatan pengaruh terhadap sifat fisik tanah yang lain seperti ketersediaan air dalam tanah. Menurut Hidayat (2015) kelas tekstur tanah menunjukkan perbandingan butir-butir pasir (0,005-2 mm), debu (0,002-0,005 mm), dan liat $(<0,002 \mathrm{~mm})$ di dalam fraksi tanah halus. Tekstur tanah lempung berdebu dikatagorikan sebagai bertekstur sedang. Tekstur tanah berkaitan dengan plastisitas, permeabilitas, kesuburan dan prduktivitas tanah. Tekstur tanah sedang memiliki tingkat 
kesesuaian lahan S1 (sesuai) untuk budidaya tanaman jagung (Widiyono, 2010)

Menurut penelitian Wirosoedarmo et al. (2011) tekstur tanah sangat berhubungan dengan jenis tanah. Tekstur tanah yang paling sesuai bagi tanaman jagung adalah tekstur yang halus atau tanah lempung. Hal ini sejalan dengan pendapat Mahmud et al. (2014) yang menyatakan lempung di anggap sebagai tanah yang mempunyai bahan organik tinggi dan optimal bagi pertumbuhan tanaman, karena kapasitas tanah dalam menahan air dan unsur hara lebih baik dibandingkan tanah berpasir, sedangkan drainase dan aerasenya lebih baik dibanding liat.

Selanjutnya, dari perlakuan yang diberikan menunjukan tidak ada pengaruh biochar terhadap struktur tanah, hal ini karena pengaruh biochar tidak memberikan nampak pada musim tanam 1 di lahan budidaya jagung. Hal ini didukung oleh Nurida et al. (2012) bahwa tidak ada pengaruh interaksi antara pembenah tanah terhadap sifat fisik tanah. Struktur tanah berperan penting dalam peningkatan laju infiltrasi pada tanah sehingga jika struktur tanah baik maka akan mudah dalam meloloskan air pada tanah (Sarminah dan Indriwan, 2017). Menurut penelitian Ardiansyah et al. (2015) struktur tanah granular terbentuk karena pengolahan tanah intensif yang dilakukan secara maksimum yaitu dengan membalik-balikkan tanah dengan kedalaman $\pm 20 \mathrm{~cm}$ sehingga terjadi penghancuran agregat tanah. Hancur dan rusaknya agregat tanah akan menyebabkan terjadinya dispersi agregat, penyumbatan pori dan rusaknya struktur tanah.

Menurut Khair et al. (2017) bahan organik dapat meningkatkan kemantapan agregat tanah dan memperbaiki struktur tanah. Tanah yang banyak mengandung bahan organik mempunyai humus yang tebal sehingga akan mempunyai sifat fisik yang baik yaitu mempunyai kemampuan menghisap air sampai beberapa kali berat keringnya dan juga memiliki porositas yang tinggi.

\section{Kerapatan Isi, Porositas dan Kadar Air Tanah}

Hasil analisis kerapatan isis, porositas dan kadar air tanah sangat penting untuk dijadikan acuan pengelolaan lahan pertanian. Data hasil analisisnya ditampilkan pada Tabel 2. Berdasarkan hasil penelitian menunjukkan bahwa kerapatan isi tanah pada lahan pembudidayaan tanaman jagung mempunyai nilai yang berbeda pada setiap sampel tanah dan dapat dikategorikan kelas S2. 
Janu: Pengaruh biochar sekam padi terhadap sifat fisik dan hasil tanaman jagung

Tabel 2. Hasil Analisis kerapatan isi Tanah, porositas dan kadar air tanah pada lahan budidaya tanaman jagung di Kelurahan Lape

\begin{tabular}{ccccc}
\hline $\begin{array}{c}\text { Kode } \\
\text { Sampel }\end{array}$ & Dosis Biochar & Kerapatan Isi & Porositas & Kadar Air \\
\hline B0 & 0 & 1.01 & 61.76 & 36.78 \\
B1 & 0.9375 & 0.9 & 65.91 & 41.14 \\
B2 & 2 & 0.87 & 67.18 & 40.82 \\
B3 & 2.81 & 0.81 & 69.41 & 35.06 \\
B4 & 3.75 & 0.80 & 69.89 & 39.55 \\
\hline
\end{tabular}

Hasil analisis regresi yang digunakan untuk mengetahui pengaruh aplikasi biochar sekam padi terhadap kerapatan isi tanah menunjukan bahwa nilai $\mathrm{R}$ Square sebesar 0,9. Artinya biochar memberi pengaruh sebesar $90 \%$ dan $10 \%$ dipengaruhi oleh faktor lain. Hal ini dapat diketahui bahwa dengan pengaplikasian biochar sekam padi dapat mengurangi kerapatan isi tanah. Khair et al.( 2017) dalam penelitiannya menyatakan bahwa kerapatan isi tanah mineral berkisar antara 1,1-1,6 $\mathrm{g} \mathrm{cm}^{3}$, baik untuk perkembangan akar tanaman dalam menembus tanah karena tidak terjadi pemadatan. Beberapa jenis tanah yang mempunyai kerapatan isi kurang dari 0,90 g/cc (misalnya tanah andosol), bahkan ada yang kurang dari $0,10 \mathrm{~g} / \mathrm{cc}$ misalnya tanah gambut (Annisah et al., 2014). Oleh sebab itu pengaplikasian biochar sekam padi belum menunjukan kerapatan isi yang baik bagi tanaman jagung karena hasil penelitian menunjukan nilai kerapatan isi yang rendah dari kondisi idealnya. Kerapatan isi tanah merupakan penunjukan kepadatan tanah, makin padat suatu tanah makin tinggi kerapatan isinya.

Penurunan kerapatan isi tanah disebabkan oleh perakaran tanaman yang berperan dalam menurunkan kerapatan isi tanah. Kerapatan isi merupakan petunjuk kepadatan tanah, semakin padat suatu tanah maka semakin tinggi kerapatan isinya yang berarti tanah semakin sulit ditembus akar tanaman. Peningkatan kandungan bahan organik tanah dapat mempertahankan kualitas fisik tanah untuk membantu perkembangan akar tanaman melalui pembentukan celah-celah yang mudah ditembus akar (Yulina et al., 2018). Jumlah akar yang semakin banyak akan meningkatkan kemampuan tanaman untuk menyerap unsur hara oleh tanaman. Oleh karena itu Nilai Kerapatan isi tanah sangat bervariasi dikarenakan perbedaan pemberian kandungan bahan organik, tekstur tanah, 
kedalaman tanah, dan kadar air tanah (Agus et al., 2006). Selain itu, kerapatan isi tanah merupakan petunjuk kerapatan tanah, makin tinggi kerapatan isi tanah makin sulit meneruskan air atau ditembus akar.

Hasil analisis regresi yang digunakan untuk mengetahui pengaruh aplikasi biochar sekam padi terhadap porositas tanah menunjukan bahwa nilai $\mathrm{R}$ Square sebesar 0,91. Hal berarti biochar memberi pengaruh sebesar $91 \%$ dan $9 \%$ dipengaruhi oleh faktor lain. Hal ini dapat diketahui bahwa dengan pengaplikasian biochar sekam padi dapat meningkatkan porositas tanah. Porositas adalah bagian tanah yang tidak terisi bagian padat tanah dimana terisi oleh udara dan air. Porositas tanah pada lahan budidaya tanaman jagung menunjukkan bahwa nilai porositas tertinggi terdapat pada sampel lima, perlakuan B4 sebesar : 69,89\% dan nilai terendah terdapat pada perlakuan B0 sebesar $61,76 \%$ dan dapat dikategorikan kelas S1 (sangat sesuai). Dengan demikian hal ini menjelaskan bahwa porositas tanah dapat dipengaruhi oleh pengaplikasian biochar sekam padi. Pertumbuhan ideal porositas tanaman jagung menghendaki dari 50\% ruang pori $25 \%$ ditempati air dan $25 \%$ udara (Toyip, 2013). Menurut Surya et al. (2017) porositas tanah dapat dipengaruhi oleh bahan organik tanah. Humus dengan partikel tanah terdapat interaksi sehingga berakibat pada struktur tanah yang lebih mantap dan akan memperbesar ruang pori. Hal ini sejalan dengan penelitian Irawan et al. (2016) keberadaan ruang pori tanah merupakan media untuk udara dalam menunjang pernafasan akar, aktivitas mikro organisme, dan penyerapan unsur hara. Sementara menurut Tolaka et al. (2013) Porositas terdiri dari ruang diantara partikel pasir, debu dan liat serta ruang diantara agregat-agregat tanah. Besarnya total ruang pori tanah menunjukkan tanah tersebut gembur dan memiliki banyak ruang pori tanah. Hal ini berarti proses penyerapan terhadap air berlangsung cepat (Elfiati dan Delvian, 2010).

Hasil analisis regresi yang digunakan untuk mengetahui pengaruh aplikasi biochar sekam padi terhadap kadar air tanah menunjukan bahwa nilai $\mathrm{R}$ Square sebesar 0,91. Hal ini berarti biochar memberi pengaruh sebesar 91\% dan 9\% dipengaruhi oleh faktor lain. Kadar air tanah pada Lahan Budidaya Tanaman jagung menunjukkan bahwa nilai kadar air tertinggi terdapat pada sampel dua, perlakuan B1 sebesar: 41,14\% dan nilai terendah terdapat pada perlakuan B3 sebesar 35,06\% dan dikategorikn kelas $\mathrm{N}$ (tidak sesuai). Dari hasil yang diperoleh dinyatakan bahwa kadar air yang terdapat di 
Janu: Pengaruh biochar sekam padi terhadap sifat fisik dan hasil tanaman jagung

lahan budidaya tanaman jagung tidak sesuai (tidak subur) dimana kadar air ini tidak dapat meningkatkan hasil produksi tanaman jagung yang optimal, karena evaporasi/penguapan terhalangi oleh tanaman yang ada disekitar. Kadar air merupakan banyaknya air yang terkandung dalam tanah yang dinyatakan dalam persen (Umin dan Anasaga, 2019).

Berdasarkan hasil penelitian Ayu et al. (2013) kadar air yang ideal 50\% - 80\%, seandainya kadar air $<50 \%$ akan mengakibatkan kerusakan pada akar tanaman jagung dan memperhambat pertumbuhan jagung, karena kandungan air rendah, sebaliknya > 80\% kandungan air sangat tinggi sehingga mengakibatkan hasil produksi jagung menurun dan tidak mendapatkan hasil yang optimal. Kadar air tanah juga berhubungan erat dengan porositas tanah, dimana porositas ini memiliki kemampuan tanah dalam menyerap air berkaitan dengan tingkat kepadatan tanah. Semakin padat tanah maka semakin sulit untuk menyerap air maka porositas tanah semakin kecil. Sebaliknya semakin mudah tanah menyerap air maka tanah tersebut memiliki porositas yang besar. Berdasarkan penelitian Pangaribuan et al. (2020) pemberian biochar merupakan alternatif yang tepat dalam meningkatkan jumlah pori mikro karena memiliki pori-pori yang halus dan bersifat porous yaitu memiliki pori dalam jumlah banyak sehingga kemampuan tanah untuk menyerap air tinggi.

\section{Suhu dan Kelembaban}

Berdasarkan hasil penelitian tentang suhu dan kelembaban tanah dilapangan yang dilakukan setiap ulangan dengan hasil pengukuran lahan tanaman jagung di desa Lape yaitu seperti pada Tabel 3 berikut.

Tabel 3. Hasil analisis suhu tanah pada lahan budidaya tanaman jagung di Kelurahan Lape

\begin{tabular}{cccc}
\hline NO & Kode Sampel & Suhu Tanah & Kelembaban Tanah \\
\hline 1 & B0 & $33.75 \mathrm{~b}$ & $67.00 \mathrm{~b}$ \\
2 & B1 & $34.00 \mathrm{~b}$ & $68.00 \mathrm{~b}$ \\
3 & B2 & $32.75 \mathrm{a}$ & 64.50 \\
4 & B3 & $33.25 \mathrm{ab}$ & 66.25 \\
5 & B4 & $34.00 \mathrm{~b}$ & 68.00 \\
\hline
\end{tabular}

Suhu tanah pada lahan budidaya tanaman jagung menunjukkan bahwa nilai suhu tertinggi terdapat pada sampel satu dan sampel empat, perlakuan B1 sebesar : 34,00
${ }^{0} \mathrm{C}$ dan B4 sebesar: $34,00{ }^{0} \mathrm{C}$ nilai terendah terdapat pada perlakuan B2 sebesar 32,75 ${ }^{0} \mathrm{C}$. Dan dapat dikategoriksn kelas N (tidak sesuai) karena suhu yang ideal untuk 
tanaman jagung yaitu $24-30{ }^{\circ} \mathrm{C}$ (Lutfiyana et al., 2017).

Temperatur tanah juga sangat mempengaruhi aktivitas mikrobial tanah dan aktivitas ini sangat terbatas pada temperatur di bawah $10{ }^{\circ} \mathrm{C}$, laju optimum aktivitas biota tanah yang menguntungkan terjadi pada temperatur $18-30{ }^{\circ} \mathrm{C}$, seperti bakteri pengikat $\mathrm{N}$ pada tanah berdrainase baik. Temperatur menyatakan intensitas atau tingkat panas yang berfungsi sebagai indikator tingkat atau derajat aktivitas molekuler (Karamina et al., 2017).

Ada beberapa faktor yang membuat tinggi rendahnya temperatur tanah yaitu radiasi matahari, awan, curah hujan, kecepatan angin dan kelembaban udara. Sedangkan untuk faktor dalam tanah yang meliputi struktur tanah, kadar air tanah, kandungan bahan organik, $\mathrm{pH}$ tanah dan warna tanah. Makin tinggi suhu tanah semakin cepat pematangan pada tanaman (Karamina et al., 2017).

Hasil uji BNT 5\% menunjukkan bahwa pada variabel kelembaban perlakuan terbaik diperoleh pada perlakuan B1; B4 dan diikuti perlakuan B0; B3 dan B2 dan dapat dikategorikan kedalam kelas S1 (sangat sesuai). Perlakuan B1; B4 tidak berbeda nyata dengan perlakuan B0; B3; tetapi berbeda nyata dengan perlakuanB2; perlakuan B2 tidak berbeda nyata dengan perlakuan B3 dan berbeda nyata dengan perlakuan B4; B0; B1. kelembaban tanah yang sesuai dengan karakteristik tanaman jagung sekitar 62,47-74,34\%, semakin rendah kelembaban tanahnya maka pertumbuhan tanaman jagung tidak akan maksimal , dan semakin tinggi kadar kelembaban tanahnya maka tanaman jagung akan layu (Paper, 2013). peran biochar bagi tanah adalah menjaga kelembaban tanah dan meningkatkan kesuburan tanah. Hal ini di dukung oleh Putri et al. (2017) pengaplikasian biochar dapat menjaga kelembaban tanah sehingga kapasitas menahan air tinggi. Kemampuan biochar yang bermanfaat mempertahankan kelembaban dapat membantu tanaman pada periode-periode kekeringan dapat berperan sebagai pemacu pertumbuhan tanaman dan menahan nutrisi dalam tanah sehingga nutrisi yang ada dalam tanah tidak mudah hilang dalam proses pencucian dalam tanah dan pada akhirnya akan berpengaruh pada peningkatan hasil panen (Kurniawan et al., 2016).

Hal ini didukung oleh penelitian Annisah et al. (2014) kelembaban udara yang terlalu rendah dan terlalu tinggi akan menghambat pertumbuhan dan pembungaan tanaman. Kelembaban udara dapat 
Janu: Pengaruh biochar sekam padi terhadap sifat fisik dan hasil tanaman jagung

mempengaruhi pertumbuhan tanaman karena dapat mempengaruhi proses fotosintesis. Laju fotosintesis meningkat dengan meningkatnya kelembaban udara sekitar tanaman. Kelembaban tanah akan menentukan ketersediaan air tanah apabila curah hujan tingggi maka kelembaban tanah juga tinggi sehingga memudahkan pertumbuhan jagung.

\section{Produksi Tanaman Jagung}

Berdasarkan hasil analisis menujukkan bahwa penaruh biochar sekam padi terhadap sifat fisik tanah dan hasil tanaman jagung, dapat memberikan pengaruh yang sangat nyata terhadap variabel hasil yan g meliputi: berat pipilan jagung $\tan ^{-1}$ dan berat pipilan jagung ha ${ }^{-1}$ yang dapat dilihat pada Tabel 9.

Tabel 9. Pengaruh Aplikasi Biochar Sekam Padi Terhadap Hasil Tanaman Jagung terhadap berat pipilan jagung $\tan ^{-1}$ dan Berat Pipilan Jagung $\mathrm{ha}^{-1}$.

\begin{tabular}{|c|c|c|c|}
\hline $\mathrm{NO}$ & Kode Sampel & $\begin{array}{c}\text { Berat Pipilan } \\
\text { Jagung } \tan ^{-1}(\mathrm{~g})\end{array}$ & $\begin{array}{c}\text { Berat Pipilan } \\
\text { Jagung ha }^{-1} \text { (ton) }\end{array}$ \\
\hline 1 & B0 & $347.30 \mathrm{a}$ & $9.26 \mathrm{a}$ \\
\hline 2 & B1 & $360.40 \mathrm{ab}$ & $9.61 \mathrm{ab}$ \\
\hline 3 & B2 & $380.70 \mathrm{bc}$ & $10.15 \mathrm{bc}$ \\
\hline 4 & B3 & $385.40 \mathrm{bc}$ & $10.28 \mathrm{bc}$ \\
\hline 5 & B4 & $401.35 \mathrm{c}$ & $10.70 \mathrm{c}$ \\
\hline
\end{tabular}

Ket: Angka yang diikuti oleh huruf yang sama pada kolom yang sama menunjukkan tidak berbeda nyata pada taraf 5\% uji BNT.

Berdasarkan hasil analisis statistik hasil tanaman jagung. perlakuan biochar menunjukkan bahwa pengaruh aplikasi dapat meningkatkan serapan tanaman biochar sekam padi terhadap hasil tanaman terhadap pupuk NPK. jagung memberikan pengaruh sangat nyata terhadap variabel hasil yang meliputi berat pipilan jagung $\tan ^{-1}(\mathrm{~g})$ dan berat pipilan jagung $\mathrm{ha}^{-1}$ (ton). Dilihat dari 5 perlakuan yang ada masing-masing perlakuan mempunyai perbedaan yang sangat nyata, dan mempunyai nilai tertinggi pada perlakuan B4 (4 ton $=3,75 \mathrm{~kg}$ ). Hal ini di sebabkan karena pengaplikasian biochar sekam padi mempunyai pengaruh terhadap
Berdasarkan hasil penelitian Verdiana et al. (2016) serapan tanaman yang semakin besar maka hasil yang diperoleh akan optimal. Perlakuan biochar mampu meningkatkan kapasitas menahan air, KTK, maupun menyediakan unsur hara dalam memperbaiki serapan hara oleh tanaman. Sehingga menyebabkan kesuburan tanah semakin tinggi. Penambahan bahan organik didalam tanah mampu meningkatkan 
perkembangan mikroorganisme didalam tanah. Salah satu peranan biochar yakni sebagai habitat untuk pertumbuhan mikroorganisme bermanfaat.

Hal ini didukung oleh penelitian Zulfita et al. (2020) biochar sekam padi memiliki pori mikro yang dapat digunakan sebagai habitat bagi mikroorganisme yang mengakibatkan berkurangnya persaingan antara mikroorganisme sehingga dapat meningkatkan aktivitas biologi tanah. Semakin tinggi aktivitas mikroorganisme tanah maka dapat meningkatkan ketersediaan unsur hara di dalam tanah sehingga tanaman dapat menyerap unsur hara dengan baik dan dapat juga meningkatkan hasil tanaman.

Perbaikan kualitas tanah akibat penambahan biochar harus berimplikasi pada peningkatan produktivitas tanaman. Produktivitas tanaman pangan seperti padi gogo dan jagung telah terbukti meningkat setelah diberi biochar. Dampak pemberian biochar terhadap produktivitas tanaman sangat tergantung pada karaketistik sifat biochar, dosis yang digunakan dan kemampuannya menanggulangi kendala utama tanah dimana biochar diaplikasikan (Nurida, 2014).

\section{SIMPULAN}

Berdasarkan hasil penelitian pengaruh biochar sekam padi terhadap sifat fisik tanah dan hasil tanaman jagung ( Zea mays L.) dapat disimpulkan bahwa kondisi Sifat fisik tanah pada lahan budidaya tanaman jagung di Desa Lape mempunyai tekstur tanah lempung berdebu dan dikategorikan kelas S1, warrna tanah didominasi oleh 10 YR 2/1 Black dan dikategorikan kelas $\mathrm{S} 1$, dan struktur tanah didominasi dengan kriteria granular. Nilai kerapatan isi B0: 1,01; B2: 0,9; B3: 0,87; B4: 0,81; B4: 0,8 dan dikategorikan kelas S2, nilai porositas tanah B0: 61,76; B1: 65,91; B2:67,18; B3: 69,41; B4; 69,89 dan dikategorikan kelas S1. Nilai kadar air B0: 36,78; B1: 41,14; B2: 40,82; B3: 35,06; B4: 39,55 dan dikategorikan ke dalam kelas N. hasil analisis suhu B0: 33,75; B1: 34,00; B2: 32,75; B3: 33,25; B4: 34,00 dan dapat dikategorikan kelas N. Hasil analisis kelembaban B0: 67.00; B1: 68,00; B2: 64,$50 ; \quad$ B3: 66,$25 ; \quad 68,00$ dan dikategorikan dalam kelas S1. Hasil pipilan jagung $\tan ^{-1}(\mathrm{~g})$ B0: 347,30; B1: 360,40; B2: 380,70; B3: 385,40; B4: 401,35. Hasil pipilan jagung ha ${ }^{-1}$ (ton) B0: 9,26; B1: 9,61; B2: 10,15; B3: 10,28; B4: 10,70.

\section{UCAPAN TERIMAKASIH}

Pada kesempatan ini kami mengucapkan terima kasih kepada semua pihak yang telah membantu dalam pelaksanaan penelitian ini yakni civitas 
Janu: Pengaruh biochar sekam padi terhadap sifat fisik dan hasil tanaman jagung

akademika Fakultas Pertanian Universitas

Flores.

\section{DAFTAR PUSTAKA}

Agus, F., R. D. Yustika, dan U. Haryati. 2006. Sifat Fisik Tanah dan Metode Analisisnya. Bogor: Balai Besar Penelitian dan Pengembangan Sumberdaya Lahan Pertanian

Akmal, S., \& Simanjuntak, H. (2019). Pengaruh Pemberian Biochar Terhadap Pertumbuhan dan hasil Tanaman Sawi Pakcoy (Brassica Rapa Subsp. Chinensis). AGRILAND Jurnal Ilmu Pertanian, 7(2), 169174.

Annisah, N., Sudhartono, A., \& Ramlah, S. (2014). Karakteristik Fisik Habitat Leda (Eucalyptus deglupta) di Jalur Pendakian Gunung Nokilalaki Kawasan Taman Nasional Lore Lindu. Warta Rimba, 2(2), 42-48.

Ayu, I. W., Prijono, S., \& Soemarno. (2013). Evaluasi Ketersediaan Air Tanah Lahan Kering di Kecamatan Unter Iwes , Sumbawa Besar. Jurnal Pembangunan Dan Alam Lestari, 4(1), 18-25.

Elfiati, D., \& Delvian. (2010). Laju Infiltrasi Pada Berbagai Tipe Kelerengan Dibawah Tegakan Ekalip[tus Di Areal HPHTI PT. Toba Pulp Lestari Sektor AEK Nauli. Jurnal Hidrolitan, 1(2), 29-34.

Fuady, Z., \& Mustaqim. (2015). Pengaruh Olah Tanah Terhadap Sifat Fisik Tanah Pada Lahan Kering Berpasir. Lentera, 15(15), 1-7.

Gomes K.A. dan Gomes A.A.. 2007. Prosedur Statistik Untuk Penelitian
Pertanian. Universitas Indonesia. Jakarta.

Herdiyanto, D., \& Setiawan, A. (2015). Upaya peningkatan kualitas tanah melalui sosialisasi pupuk hayati, pupuk organik, dan olah tanah konservasi di Desa Sukamanah dan Desa Nanggerang Kecamatan Cigalontang Kabupaten Tasikmalaya. Jurnal Aplikasi Ipteks Untuk Masyarakat, 4(1), 47-53. https://doi.org/10.24198/DHARMAK ARYA.V4I2.10028

Herman, W., \& Resigia, E. (2018). Pemanfaatan Biochar Sekam Dan Kompos Jerami Padi Terhadap Pertumbuhan Dan Produksi Padi (Oryza Sativa) Pada Tanah Ordo Ultisol. Jurnal Ilmiah Pertanian, 15(1), 42-50. https://doi.org/10.31849/jip.v15i1.14 87

Holilullah, Afandi, \& Novpriansyah, $H$. (2015). Karakterisitk Sifat Fisik Tanah Pada Lahan Produksi Rendah Dan Tinggi Di PT Great Giant Pineapple. Jurnal Agrotek Tropika, 3(2), 278-282.

Karamina, H., Fikrinda, W., \& Murti, A. T. (2017). Kompleksitas pengaruh temperatur dan kelembaban tanah terhadap nilai $\mathrm{pH}$ tanah di perkebunan jambu biji varietas kristal (Psidium guajava 1.) Bumiaji, Kota Batu. Kultivasi, 16(3), 430-434. https://doi.org/10.24198/kultivasi.v16 i3.13225

Khair, refki K., Utomo, M., Afandi, \& Banuwa, I. S. (2017). Pengaruh olah tanah dan pemupukan nitrogen jangka panjang terhadap bobot isi, ruang pori total, kekerasan tanah dan 
produksi tanaman jagung (zea mays 1.) Di lahan polinela Bandar lampung. Jurnal Agroteknologi Tropika, 5(3), 175-180.

Khoiriyah, A. N., Prayogo, C., \& Widianto. (2016). Kajian Residu Biochar Sekam Padi, Kayu dan Tempurung Kelapa Terhadap Ketersediaan Air Pada Tanah Lempung Berliat. Jurnal Tanah Dan Sumberdaya Lahan, 3(1), 253-260.

Kresnatita, S., Koesriharti, K., \& Santoso, M. (2013). Pengaruh Rabuk Organik Terhadap Pertumbuhan Dan Hasil Tanaman Jagung Manis. Indonesian Green Technology Journal, 2(1), 817. Kresnatita, S., Koesriharti, K., \& Santoso, M. (2013). Pengaruh Rabuk Organik Terhadap Pertumbuhan Dan Hasil Tanaman Jagung Manis. Indonesian Green Technology Journal, 2(1), 8-17.

Kurniawan, A., Haryono, B., Baskara, M., \& Tyasmoro, S. Y. (2016). Pengaruh Penggunaan Biochar Pada Media Tanam Terhadap Pertumbuhan Bibit Tanaman Tebu ( Saccharum officinarum L .). Jurnal Produksi Tanaman, 4(2), 153-160.

Lutfiyana, Hudallah, N., \& Suryanto, A. (2017). Rancang Bangun Alat Ukur Suhu Tanah, Kelembaban Tanah, dan Resistansi. Jurnal Teknik Elektro, 9(2), 80-86. https://doi.org/10.15294/jte.v9i2.1108 7

Mahmud, Wardah, \& Bau, T. (2014). Sifat Fisik Tanah di Bawah Tegakan Mangrove di Desa Tumpapa Kecamatan Balinggi Kabupaten Parigi Moutong. Warta Rimba, 2(1), 129-135.
Margolang, R. D., Jamilah, J., \& Sembiring, M. (2015). Karakteristik Beberapa Sifat Fisik, Kimia, Dan Biologi Tanah Pada Sistem Pertanian Organik. Jurnal Online Agroekoteknologi, 3(2), 717-723. https://doi.org/10.32734/jaet.v3i2.103 58

Nurida, N L, Sutono, \& Rachman, A. (2012). Potensi Pembenah Tanah Biochar Dalam Pemulihan Sifat Tanah Terdegradasi Dan Peningkatan Hasil Jagung Pada Typic Kanhapludults Lampung. Buana Sains, 12(1), 6974.

Pangaribuan, E. A. S., Darmawati, A., \& Budiyanto, S. (2020). Pertumbuhan dan Hasil Tanaman Pakchoy Pada Tanah Berpasir Dengan Pemberian Biochar dan Pupuk Kandang Sapi. Agrosains: Jurnal Penelitian Agronomi, 22(2), 72-78. https://doi.org/10.20961/agsjpa.v22i2 .42093

Paper, T. (2013). Kajian Kelembaban Tanah dan Kebutuhan Air Beberapa Varietas Hibrida DR UNPAD. Jurnal Keteknikan Pertanian, 1(1), 107-115.

Putri, V. I., Mukhlis, \& Hidayat, B. (2017). Pemberian Beberapa Jenis Biochar Untuk Memperbaiki Sifat Kimia Tanah Ultisol Dan Pertumbuhan Tanaman Jagung. Agroekoteknologi, 5(4), 824-828. https://doi.org/10.32734/jaet.v5i4.164 35

Sarminah, S., \& Indriwan. (2017). Kajian Laju Infiltrasi Pada Beberapa Tutupan Lahan. AGRIFOR, XVI(1995), 301-310.

Simanjuntak, A., Lahay, R. R., \& Purba, E. 
Janu: Pengaruh biochar sekam padi terhadap sifat fisik dan hasil tanaman jagung

(2013). Respon Pertumbuhan Dan Produksi Bawang Merah (Allium ascalonicum. L) Terhadap pemberian Pupuk NPK Dan Kompos Kulit Buah Kopi. Jurnal Online Agroteknologi, 1(3), 362-373.

Surya, J. A., Nuraini, Y., \& Widianto. (2017). Kajian Porositas Tanah Pada Pemberian Beberapa Jenis Bahan Organik Di Perkebunan Kopi Robusta. Jurnal Tanah Dan Sumberdaya Lahan, 4(1), 463-471.

Syaikhu, A. H. F., Hariyono, B., \& Suprayogo, D. (2016). Uji kemanfaatan biochar dan bahan pembenah tanah untuk perbaikan beberapa sifat fisik tanah berpasir serta dampaknya terhadap pertumbuhan dan produksi tebu. Jurnal Tanah Dan Sumberdaya Lahan, 3(2), 345-357.

Tolaka, W., Wardah, \& Rahmawati. (2013). Sifat Fisik Tanah Pada Hutan Primer, Agroforestri Dan Kebun Kakao Di Subdas Wera Saluopa Desa Leboni Kecamatan Pamona Puselemba Kebupaten Poso. Warta Rimba, 1(1), $1-8$.

Toyip. (2013). Respon Pertumbuhan Tanaman Kangkung (Ipomoea Reptans Poir) Terhadap Berbagai Interval Penyiraman Dan Dosis Pemupukan Npk Pada Media Tanah + Arang Sekam (1+1). Jurnal Agropet, 10(2), 8-16.

Umin, M., \& J.P. Anasaga, A. (2019). Karakteristik Sifat Fisik Tanah Pada Lahan Budidaya Ubi Kayu (Manihot Esculenta Crantz) Di Desa Wologai Tengah. Agrica, 12(1), 23-33. https://doi.org/10.37478/agr.v12i1.9
Verdiana, M. A., Sebayang, H. T., \& Sumami, T. (2016). Pengaruh Berbagi Dosis Biochar Sekam Padi dan Pupuk NPK terhadap Pertumbuhan dan Hasil Tanaman Jagung (Zea mays L .). Jurnal Produksi Tanaman, 4(8), 611-616.

Wahyudin, A., Ruminta, R., \& Nursaripah, S. A. (2017). Pertumbuhan dan hasil tanaman jagung (Zea mays L.) toleran herbisida akibat pemberian berbagai dosis herbisida kalium glifosat. Kultivasi, 15(2), 86-91. https://doi.org/10.24198/kltv.v15i2.1 1867

Widiastuti, M. M. D., \& Lantang, B. (2017). Ketersediaan Nitrogen Pada Tiga Jenis Tanah Akibat Pemberian Tiga Bahan Organik Dan Serapannya Pada Tanaman Jagung. Agrokreatif Jurnal Ilmiah Pengabdian Kepada Masyarakat, 3(2), 129-135. https://doi.org/10.29244/agrokreatif.3 .2.129-135

Widiyono, W. (2010). Inventarisasi JenisJenis Tumbuhan Dan Kesesuaian Lahan Untuk Konservasi Daerah Tangkapan Sumber Mata Air 'Wetihu' Desa Baudaok Kecamatan Tasifeto Timur - Belu. Jurnal Teknologi Lingkungan, 11(3), 353361.

https://doi.org/10.29122/jtl.v11i3.118 0

Widodo, K. ., \& Kusuma, Z. (2018). Pengaruh Kompos Terhadap Sifat Fisik Tanah Dan Pertumbuhan Tanaman Jagung Di Inceptisol. Jurnal Tanah Dan Sumberdaya Lahan, 5(2), 959-967.

Wirosoedarmo, R., Sutanhaji, A., Kurniati, E., \& Wijayanti, R. (2011). Evaluasi 
AGRICA, VOL. 14, NO. 1 (2021)

Kesesuaian Lahan Untuk Tanaman Jagung Menggunakan Metode Analisis Spasial. Agritech: Jurnal Fakultas Teknologi Pertanian UGM, 31(1), 71-78.

Yulina, H., Harryanto, R., \& Devnita, R. (2018). Respon Air Tersedia dan Bobot Isi Tanah pada Tanaman Jagung Manis dan Brokoli terhadap Kombinasi Terak Baja dan Bokashi
Sekam Padi pada Andisol, Lembang. Agrikultura, 29(2), 66. https://doi.org/10.24198/agrikultura.v 29i2. 19248

Zulfita, D., Surachman, \& Santoso, E. (2020). Aplikasi Biochar Sekam Padi Dan Pupuk NPK Terhadap Serapan N, P, K Dan Komponen Hasil Jagung Manis Di Lahan Gambut. Jurnal Ilmiah Hijau Cendekia, 5, 42-49. 